\title{
Penggunaan Model Pembelajaran Eklektik dalam Meningkatkan Prestasi Belajar Bahasa Indonesia dengan Kovarian Kognisi di Sekolah Inklusif
}

\author{
Gunarhadi \\ Prodi PLB FKIP UNS, Email: gunhardi1202@yahoo.com
}

\begin{abstract}
Abstrak: Tujuan penelitian ini adalah untuk mengetahui ada tidaknya dampak model pembelajaran Eklektik terhadap prestasi belajar, mengetahui seberapa besar dampak model pembelajaran Eklektik terhadap prestasi belajar, dan mengetahui peran kognisi dalam mempengaruhi perubahan hasil belajar siswa. Penelitian dilaksanakan terhadap sampel yang diambil secara acak melalui cluster random sampling dari sejumlah 75 Sekolah Dasar penyelenggara pendidikan inklusi di Kabupaten Boyolali. Metode penelitian ini adalah experimen tidak penuh (quasi experiment) dengan menggunakan 68 siswa kelas VI SD yang dibagi menjadi kelompok eksperimen dan kelompok kontrol. Data peneltian dianalisis melalui ANAKOVA dengan cara membandingkan hasil belajar sebelum dan setelah perlakuan dan membandingkan hasil belajar kelompok eksperimen dan kelompok kontrol dengan mempertimbangkan pengaruh kognisi. Hasil penelitian menyimpulkan bahwa: model pembelajaran eklektik memberikan pengaruh signifikan pada prestasi belajar siswa, model pembelajaran eklektik lebih effektif dibanding dengan metode tradisional, peningkatan hasil belajar siswa juga dipengaruhi oleh kemampuan kognisi siswa.
\end{abstract}

Kata kunci: eklektik, prestasi akademik, kovarian, kognisi. dan sekolah inklusif

\begin{abstract}
This research aims to know the impact of eclectic teaching model, measure the extent of eclectic teaching model on the learning achievement, and measure the role of cognition in facilitating the learning achievement of Bahasa Indonesia. This research was conducted to a group of students in 75 inclusive elementary schools in Boyolali assigned in cluster random sampling. Quasi experiment was applied for 68 sixth graders representing both experiment and control groups. The data was analyzed by means of ANCOVA as to compare the learning achievement before and after treatment, between both experiment and control groups as controlled by cognition. The research come to conclusion that: eclectic teaching model gave significant impact of the student learning achievement, eclectic teaching model was more effective than conventional teaching method, the cognition turned to take role to the improvement of the student learning achievement.
\end{abstract}

Key words: eclectic, academic achievement, moderation, cognition, and inclusive school.

\section{Pendahuluan}

Penggunaan metode konvensional belum sepenuhnya memenuhi kebutuhan inovasi pembelajaran dalam rangka meningkatkan kualitas pembelajaran yang pada gilirannya dapat meningkatkan kualitas akademik siswa. Meskipun demikian, metode ini masih banyak digunakan di berbagai tempat di dunia ini (Watkins, 2003). Demikian juga di Indonesia, sebagian besar guru mengajar dengan hanya mentransfer materi yang terdapat dalam kurikulum (Buchori, 2007). Model pembelajaran yang demikian menggambarkan perlunya meningkatkan kompetensi pedagogik guru dalam dunia pendidikan.
Pembelajaran konvensional juga masih banyak diterapkan dalam mata pelajaran Bahasa Indonesia. Meskipun bahasa indonesia memiliki berbagai komponen kebahasaan, model pembelajaran cenderung tidak variatif. Guru berperan sangat domoinan dan menjadi tumpuan akhir segala persoalan belejar siswa dan menjadi satusatunya sumber pengetahuan berdasarkan tuntutan penyelesaian materi yang bersifat kurukuler (text book-oriented). Bahasa Indonesia terkesan identik dengan membaca pemahaman. Keterampilan menulis identik dengan menulis rapi dan mengarang bebas berdasarkan topik yang ditetapkan guru. Sastra identik dengan puisi yang 
ditekankan pada membaca indah. Aspek kreativitas siswa pada komponen-komponen bahasa belum banyak memperoleh peluang belajar secara konstruktif dalam menyelesaikan persoalan sendiri untuk memperoleh pengetahuan melalui pembelajaran.

Model-model pembelajaran yang menekankan belajar siswa aktif sudah banyak dikembangkan di Indonesia. Manajemen berbasis sekolah (MBS) yang mengembangkan pemberdayaan otonomi sekolah, misalnya, sudah dikembangkan selama kurang lebih 10 tahun. Salah satu bidangnya adalah peningkatan pembelajaran yang menekankan siswa aktif belum merupakan bagian utama dalam meningkatkan mutu pembelajaran. (Bambang Saptono, 2006). Demikian juga dengan program Decentralized Based-Education (DBE) sudah beberapa tahap dikembangkan di Indonesia. Dengan kegiatan yang tidak jauh berbeda dengan MBS, pembelajaran yang menekankan siswa aktif pada $D B E$ diujicobakan pada daerah-daerah tertentu di Indonesia. Namun, pengembangan MBS dan $D B E$ tersebut bersifat sporadik dengan memilih daerah tertentu sebagai pusat kegiatan sehingga belum semua sekolah terutama guru memiliki pengetahuan dan keterampilan dan mengembangkannya dalam tugas pembelajaran sehari-hari. Dengan demikian diasumsikan bahwa masih banyak guru yang belum memahami dan melaksanakan kegiatan-kegiatan senada yang menekankan pembelajaran yang berpusat pada siswa. Model pembelajaran eklektif merupakan alternatif yang ditandai dengan siswa belajar bagaimana belajar secara aktif dan kreatif.

Model pembelajaran eklektik menggabungkan berbagai metode yang dikemas dalam satu model pembelajaran (Januwszweski \& Molenda, 2008). Model pembelajaran eklektik disarikan dari beberapa prinsip dan teori belajar kognitivisme dan konstruktivist dan behaviorisme. Prinsipprinsip belajar dari tiga teori inilah yang kemudian memberikan inspirasi yang seyogyanya direalisasikan seorang guru dalam melakukan tindakan pembelajaran Bahasa melalui berbagai metode sesuai komponen bahasa baik yang bersifat pengetahuan maupun keterampilan yang diajarkannya. Prinsip belajar ini pula yang membangkitkan guru untuk menciptakan lingkungan belajar yang kondusif sehingga merangsang kreativitas siswa dalam proses belajar. Oleh karena itu, dirasakan perlu mengembangkan metode yang memungkinkan siswa menggunakan daya kreativitasnya dalam merespon lingkungan belajar yang dilahirkan dari kreativitas guru.

Masalah kognisi pada siswa sekolah inklusi menjadi bagian penting yang harus diperhatikan dalam pembelajaran, terutama bagi siswa berkesulitan belajar bahasa. Sekolah inklusif merupakan realisasi pendidikan untuk semua (education for all) yang memberikan respon positif terhadap perbedaan dan kebutuhan individu untuk memperoleh pendidikan Ainscow (2003). Namun, kenyataan pada pembelajaran konvensional, prinsip tersebut belum digarap secara optimal terutama bagi siswa yang mengalami hambatan kognisi. Oleh karena itu, aspek kognisi tersebut perlu dikembangkan dan dikaji dampaknya terhadap prestasi belajar terutama berkaitan dengan keterampilan menyimak dan menulis.

Penelitian ini mengkaji bagaimana model pembelajaran eklektik memberikan dampak akademik pada siswa dan bagaimana peran kognisi terhadap perubahan yang dihasilkan dari model pembelajaran tersebut dalam aspek-aspek kebahasaan. Aspek-aspek terebut meliputi keterampilan menyimak, membaca, menulis, dan berbicara serta bahasa sebagai pengetahuan dan seni yang meliputi tata bahasa, kosa kata, dan sastra.

\section{Kajian Literatur}

\section{Model Pembelajaran Eklektik}

Model pembelajaran eklektik merupakan model pembelajaran yang diramu dari beberapa pendekatan atau teori belajar. Strategi ini berangkat dari asumsi bahwa setiap teori belajar berupaya menggambarkan pandangannya tentang bagaimana manusia belajar. Implikasinya adalah bahwa setiap teori belajar melahirkan metode mengajar untuk guru yang paling cocok dengan umur dan kematangan peserta didiknya.

Model pembelajaran eklektik memandang bahwa teori dan praktik dapat menghasilkan kinerja yang baik melalui berbagai cara atau 
dengan cara menggabungkan berbagai cara (Robinson, Molenda, dan Rezabek, dalam Januszweski dan Molenda, 2008). Setidaknya ada tiga teori belajar yang tergabung dalam strategi pemebelajaran eklektik; yaitu behaviorisme, kognitivisme dan konstruksivisme, serta humanisme (Januszewski \& Molenda, 2008). Teori belajar behaviorisme memandang bahwa belajar merupakan perubahan perilaku yang dihasilkan dari pengalaman dan interaksi dengan dunia (Driscoll, 2005). Behaviorisme menganggap bahwa pikiran adalah sebuah kotak hitam (black box) sehingga apa yang terjadi dalam pikiran selama proses belajar tidak bisa diketahui. Perilaku merupakan konsekuensi atau indikator terjadinya proses dalam pikiran seseorang dalam merespon suatu stimulus. Sedangkan pengetahuan atau hasil belajar diperoleh dari kegiatan merespon terhadap rangsangan yang ada pada lingkungannya (Galloti, 2004). Dengan demikian proses belajar terjadi melalui penyerapan terhadap hal-hal yang menyenangkan sebagai penguatan positif sehingga menimbulkan keinginan untuk mengulang-ulang. Implikasinya dalam pembelajaran, tugas guru adalah menghidupkan respon siswa dengan menyediakan lingkungan stimuli yang positif serta memberi penguatan (reinfocement) agar siswa mau melakukannya sebagai tindak kebiasaan.

Unsur kedua yang menjadi bagian strategi pembelajaran eklektik adalah teori kognitivisme. Teori ini menganggap bahwa manusia dilahirkan penuh dengan potensi yang menjadi bagian penting dalam proses belajar (Galloti, 2004). Belajar merupakan proses internal berupa kegiatan mental untuk memanipulasi informasi, menyimpan, dan merepresentasikan ide yang telah diserapnya (Parkin, 2000; Galloti, 2004). Aktivitas mental seperti pengamatan, memperhatikan, berpikir, memberikan alasan atau argumentasi, mengelompokkan, membuat keputusan, dan aktivitas mental lainnya membentuk skema atau pola pikir dalam diri seseorang (Januszewski \& Molenda, 2008). Schema pikir merupakan struktur konseptual yang menyimpan pengetahuan dalam ingatan jangka panjang. Dengan demikian, belajar merupakan kerja schema dalam menghimpun dan mencocokkan (assimilation) dan menata informasi (accomodation) yang diperoleh melalui interaksi dengan lingkungannya (Pritchard, 2005). Skema konseptual ini terus berkembang dan membentuk skema baru yang seiring dengan informasiinformasi baru yang tidak cocok dengan skema yang sudah ada.

Penambahan dan pembentukan schema baru pada proses belajar yang dilakukan sendiri oleh siswa itulah yang kemudian muncul menjadi teori konstruksivisme (Pritchard, 2005). Pengetahuan bukanlah sekedar tiruan tentang dunia di luar individu sehingga tidak diperoleh melalui penyerapan secara pasif atau tidak pula diperoleh melalui transfer dari orang lain. Pengetahuan bukan diperoleh melainkan dibangun. Dengan demikian belajar adalah proses membangun pengetahuan melalui pengertian dan pemahaman yang dilakukan sendiri oleh siswa (LaRocque \& Darling, 2008). Implikasinya dalam pembelajaran, tugas guru adalah memahami potensi skema kognitif tersebut dan menciptakan lingkungan serta memfasilitasi proses kerja siswa dalam menumbuhkembangkan kreativitasnya. Dengan demikian siswa dapat membangun pengetahuannya melalui pemecahan masalah pada tugas-tugas autentik secara kolaboratif dengan kreativitasnya sendiri. Hal ini dapat dilakukan dengan cara melibatkan siswa dalam kegiatan yang membangkitkan minat, mendorong siswa melakukan percobaan, dan melibatkan kerja sama dalam kelompok (DeVries, et al., 2002).

\section{Prestasi akademik di Sekolah inklusif}

Sekolah inklusif adalah sekolah yang mengimplementasikan hak atas pendidikan untuk semua termasuk mereka yang karena keterbatasannya mengalami hambatan belajar (Hallahan \& Kauffman, 2003). Mereka memiliki hak yang sama dengan semua anak lain untuk bersekolah, berpartisipasi, dan dapat memperoleh pendidikan yang berkualitas (Burstein, Sears, Wicoxson, Cabello, \& Spagna, 2004). Hal ini mengimplikasikan bahwa sekolah dituntut untuk memfasilitasi mereka dalam memperloleh kesempatan yang sama bagi semua anak untuk berprestasi.

Batasan prestasi akademik selalu terkait dengan kurikulum dan standar kompetensi pada proses pembelajaran. Kurikulum adalah materi 
yang harus disampaikan kepada murid dalam bentuk pembelajaran. Sedangkan standar kompetensi adalah kemampuan yang harus dicapai siswa melalui fungsi mental yang dimilikinya. Zimmerman dan Schunk (2001) mengatakan bahwa kekuatan fungsi mental berdampak sangat luas terhadap prestasi akademik. Fungsi mental ini relatif tidak berubah meskipun terjadi perubahan umur atau tingkat kelas siswa. Dengan demikian, prestasi akademik merupakan hasil bagaimana siswa belajar diperoleh dari asesmen melalui tes setelah mendapatkan pembelajaran dari guru.

Tinggi rendahnya pencapaian prestasi akademik yang dicapai siswa mencerminkan kadar kinerja yang dilakukan baik oleh siswa maupun guru. Prestasi akademik mencerminkan kedudukan siswa dalam kelasnya. Seorang siswa dengan prestasi akademik di atas rata-rata menggambarkan bahwa siswa tersebut memiliki kemampuan menguasai materi lebih dari cukup dan diprediksikan dapat berhasil mencapai standar yang ditetapkan dalam kurikulum. Demikian sebaliknya, siswa dengan prestasi di bawah rata-rata dapat dikategorikan siswa berprestasi rendah yang sering disebut dengan underachievers atau struggling learners (Bloom, 1982). Mereka sudah bekerja keras namun prestasinya belum dapat mencapai standar yang ditetapkan meskipun telah diberi kesempatan memanfaatkan fasilitas dan sumber belajar yang sama dengan teman sebayanya.

\section{Aspek prestasi Akademik}

Salvia dan Ysseldyke (1995) menyebutkan bahwa prestasi akademik merupakan hasil pengukuran yang meliputi tiga ranah yaitu; akademik, perilaku, dan fisik. Ranah akademik menyangkut kemampuan yang diperoleh siswa tes pada seluruh bidang studi yang dipelajarari. Ranah perilaku berupa kemampuan untuk mengadaptasi dengan aturan, teman, dan lingkungannya. Ranah fisik terkait erat dengan kemampuan unjuk kerja dan koordinasi antara pengindraan dan gerak tubuh.

\section{Hambatan Kognitif}

Aspek prestasi akademik yang disebutkan Salvia dan Ysseldyke (1995) merupakan kondisi yang menjadi dasar dan sumber terjadinya hambatan belajar. Burden dan Byrd (2003) menyebutkan setidaknya ada delapan (8) kondisi baik internal maupun eksternal yang menjelaskan apakah seorang siswa dikatakan memiliki kinerja tinggi atau rendah. Kondisi-kondisi tersebut meliputi: 1) kinerja kognitif, 2) kinerja afektif, 3) kinerja fisik, 4) kebiasaan dan tipe belajar, 5) potensi kreatif, 6) ragam budaya, 7) kecacatan dan siswa beresiko, dan 8) status sosial dan ekonomi.

Di sekolah inklusif, kondisi- kondisi tersebut dapat menjadi pendorong atau penghambat prestasi akademik siswa. Dampak negatif kondisikondisi paling sering dialami oleh siswa-siswa di kelas inklusif sebagai hambatan belajar (learning barriers) adalah hambatan kognitif. Sebagai penentu prestasi akademik, teori kognitif mempercayai bahwa seorang siswa yang memiliki kemampuan kognitif tinggi cenderung menunjukkan penguasaan hasil belajar yang baik (Bruning, 2004). Pendapat ini juga dikuatkan oleh Veemann dan Elshout (dalam Bruning, 2004) yang melakukan penelitian terhadap 496 siswa dan menyimpulkan bahwa ada hubungan antara kemampuan intelektual dengan hasil hasil belajar, dan demikian sebaliknya. Penelitian ini berimplikasi bahwa kemampuan kognitif yang rendah menjadi penghambat untuk mencapai prestasi belajar. Hal ini juga sesuai dengan pendapat Smith (2004) yang mengemukakan bahwa kegagalan mencapai standard hasil belajar lebih banyak dipengaruhi oleh proses kognitif lantaran rendahnya strategi operasi mental, kesulitan mengolah informasi, dan kesulitan mengungkapkan kembali apa yang telah dipelajari. Kegagalan ini dimungkinkan karena kemampuan mental di bawah rata-rata atau karena kesulitan belajar lain yang dialami siswa dalam bidang akademik tertentu atau kesulitan belajar spesifik (unexpected underachievers). Mereka memiliki kemampuan intelektual rata-rata, bahkan di atas rata-rata sama seperti teman lainnya, tetapi memiliki hambatan dalam hal membaca, menulis, atau berhitung (Harwell, 2001). Oleh karena itu, penenlitian ini mengungkapkan peran kognisi sebagai kovarian yang mempengaruhi prestasi belajar Bahasa indonesia melalui pembelajaran eklektik. 


\section{Metode Penelitian \\ Desain Penelitian}

Penelitian ini menggunakan pendekatan kuantitatif melalui eksperimen dan strategi pembandingan. Dikatakan kuantitatif karena penelitian menggunaka data angka atau penghitungan kuantitas (Sutrino Hadi, 2004). Penelitian ini dikatakan eksperimen karena penelitian ini menyelididki dampak sebab akibat yang diperoleh melalui perlakuan. Melalui eskperimen inilah data pada variabel terikat diperbandingkan sebelum dan sesudah perlakuan antara kelompok dalam penelitian tersebut (Sekaran, 2003).

Ekperimen penelitian ini bersifat quasi (quasi experiment) atau eksperimen tidak penuh mengingat subjek penelitian ini berupa kelompok kelas yang utuh (intact group) yang tidak mungkin dipilah pilah secara acak dan dipisahkan untuk mendapat perlakuan. Kerangka operasional penelitian eksperimen tidak penuh ini menggunakan desain yang kemukakan oleh Sekaran (2003) disebut "Posttest Only Control Group and Experiment Design". Desain tersebut dapat digambarkan pada Diagram 1.

Diagram 1. Desain Kontrol Grup

\begin{tabular}{lcc} 
GROUP & TREATMENT & POSTTEST \\
\hline EKSPERIMENT & $\mathrm{X}$ & 0.2 \\
KONTROL & & 0.4 \\
\hline
\end{tabular}

Treatment effect $=((02-01)-(04-03)$

Untuk meyakinkan adanya perubahan prestasi akademik Bahasa Indonesia, perlakuan diberikan secara serial selama tiga kali dalam kurun waktu tiga bulan dengan pelaksanaan postes satu kali setiap bulan. Hal ini dimaksudkan untuk meningkatkan validitas penelitian tersebut (Solso \& Mc.Lin, 2002).

\section{Analisis Data}

Data yang diperoleh setelah perlakuan diolah melalui bivariate dan multivariate. Teknik analisis bivariate digunakan untuk membandingkan hasil perlakuan antara kelompok eksperimen dengan kelompok kontrol. Teknik analisis multivariate digunakan untuk mem-bandingkan hasil setelah perlakuan variabel bebas terhadap variabel terikat dengan mempertimbangkan pengaruh variabel ekstra (covariate) terhadap variabel terikat. Untuk itu digunakan analisis ANAKOVA. Sekaran (2003) menyebutkan analisis ini digunakan untuk mengendalikan variabel luar (extraneous varible) yang mungkin mempengaruhi variable terikat. Melalui pengolahan data Statistik SPSS 15 dampak variabel bebas terhadap variable terikat dapat diketahui. Demikian juga akan dapat terlihat ada atau tidaknya pengaruh variabel luar terhadap variable terikat. Dalam hal ini, yang menjadi variabel luar adalah kognisi yang mungkin mempengaruhi prestasi akademik Bahasa Indonesia setelah mendapat perlakuan model pembelajaran Eklektik.

\section{Hasil dan Bahasan}

Sesuai dengan tujuan, penelitian ini menyelidiki dampak model pembelajaran eklektik terhadap prestasi belajar Bahasa Indonesia. Untuk mengetahui perubahan hasil perlakuan model pembelajaran eklektik terhadap prestasi akademik Bahasa Indonesia dari kemampuan awal (baseline), digunakan t-tes. Untuk mengetahui dampak model pembelajaran Eklektik dan pengaruh kognisi terhadap prestasi baik antara sebelum dan sesudah perlakuan maupun antara kelompok eksperimen maupun kelompok kontrol digunakan ANAKOVA.

\section{Hasil perlakuan pembelajaran model eklektik}

Skore prestasi belajar Bahasa Indonesia dari baseline sampai dengan tiga kali postes menunjukkan adanya peningkatan secara konstan. Skore pada kelompok eksperimen naik dari baseline ( 6.16$)$, postes 1 (7.28), postes 2 (7.73), dan postes 3 ( 8.00$)$. Sedangkan pada kelompok kontrol perubahan terjadi dari baseline (6.39), postes 1 (6.57), postes 2 (6.39), postes 3 (7.14).

Dengan menggunakan T-tes, perbandingan pengaruh pembelajaran Eklektik terhadap prestasi belajar Bahasa Indonesia antara kelompok eksperimen dengan kelompok kontrol terlihat perbedaan nilai rerata pada kelompok eksperimen $(8,00)$ lebih besar dibandingkan dengan nilai rerata kelompok kontrol $(7,14)$. Dengan demikian prestasi kelompok yang mendapatkan perlakuan 
lebih baik dibanding kelompok yang tidak mendapat perlakuan pembelajaran model eklektik. Perbedaan antara dua kelompok tersebut cukup berarti dengan taraf signifkasi 0,001 lebih kecil dari 0.05 .

Hal ini terjadi karena pembelajaran Bahasa Indonesia dengan menggunakan model eklektik yang menggunakan berbagai metode yang sesuai dengan materi ajar baik berupa pengetahuan maupun keterampilan memberikan dampak pada kreativitas siswa. Dengan metode drama misalnya siswa dapat tertarik dan secara kognitif mereka dengan senang hati menhafal teks atau puisi yang ditugaskan untuk dipelajari. Dengan berkunjung ke tempat atau lingkungan dirancang guru, siswa dapat memperoleh gagasan-gagasan sebagai bahan siswa dalam pengembangan keterampilan menulis.

Perbedaan prestasi belajar Bahasa Indonesia antara kelompok eksperimen dengan kelompok kontrol dengan kovarian kognisi menunjukkan bahwa terdapat perbedaan significan pada prestasi belajar Bahasa indonesia yang dihasilkan dari model pembelajaran eklektik dibandingkan dengan pembelajaran konvensional. Perbedaan significan terlihat dari nilai signifikansi (p).0.00 $<0,05$. dan Fo $=18,337>F_{t}=3,99$, dengan df $(1 ; 65)$. Angka statistik tersebut menunjukkan dengan taraf signifkansi 5\%. membuktikan bahwa pebedaan prestasi belajar Bahasa Indonesia antara kelompok eksperimen dengan kelompok konvensional cukup signifikan.

Melalui ANAKOVA terlihat pula bahwa kognisi memberikan pengaruh terhadap prestasi yang dihasilkan dari pembelajaran eklektik. Nilai signifikansi $(p) 0.00<0.05$, dan Fo $(31.77)>\mathrm{Ft}$ (3.99), membuktikan bahwa kognisi memberi pengaruh yang signifikan pada prestasi belajar Bahasa Indonesia. Dengan demikian dapat disimpulkan bahwa perubahan prestasi belajar Bahasa Indonesia tidak hanya disebabkan adanya perlakuan model pembelajaran eklektik, melainkan juga karena pengaruh kognisi.

Pembelajaran eklektif pada mata pelajaran Bahasa Indonesia mengangkat kekuatan siswa dari sisi perubahan perilaku melalui penguatan (reinforcement) terhadap keberhasilan yang siswa peroleh, menghargai potensi yang ada pada siswa, dan mendasarkan pembeajaran pada pengetahuan yang sudah dimilikinya Di samping itu, pembelajaran eklektik juga membuktikan bahwa setiap siswa memiliki kekuatan kognisi yang dibawa sejak lahir. Tugas guru lebih terfokus pada kegiatan yang memberikan stimulasi agar siswa mengkonstruk pengetahuan sendiri melalui informasi lewat lingkungan belajar yang disediakannya. Belajar adalah proses asimilasi dan juga proses akomodasi (Januszewski \& Molenda, 2008). Proses asimilasi terjadi melalui penyesuaian pengetahuan dengan pola pikir yang sudah ada pada struktur mental siswa, sedangkan proses akomodasi adalah pembentukan atau modifikasi pola pikir baru karena adanya pengetahuan belum pernah dialaminya.

Penelitian juga membuktikan bahwa kognisi memiliki pengaruh yang signifikan dalam proses pembelajaran. Hal ini dikuatkan oleh Parkin (2000) dan Galloti (2004) yang mengatakan bahwa proses belajar tidak bisa lepas dari kegiatan mental (cognitive skills). Menurut mereka belajar adalah proses mental yang meliputi aktivitas mengamati, menalar, menklasifikasi, membuat keputusan, dan kegiatan mental lainnya melalui interaksi dengan lingkungannya.

Hasil penelitian yang dilakukan Rukayah, Yenny, \& Gunarhadi (2008) juga menyimpulkan bahwa proses mental menyangkut penalaran dalam menghubungkan fakta atau informasi yang diperoleh melalui pengamatan sampai pada suatu kesimpulan. Dalam pembelajaran Bahasa Indonesia dengan menggunakan model eklektik, proses kognitif tampak nyata pada siswa dan terjadi secara konstant pada waktu mereka harus mencerna informasi melalui keterampilan menyimak, membaca, menulis, berbicara, pemahaman tata bahasa dan pengembangan kosa kata.

\section{Simpulan dan Saran}

\section{Simpulan}

Dari uraian hasil analisis data terkait dengan kajian teoritik, penelitian ini menyimpulkan hal- hal sebagai berikut.

Pembelajaran dengan model eklektik memberikan pengaruh positif terhadap peningkatan prestasi belajar Bahasa Indonesia. Hal ini mengimplikasikan perlunya seorang guru untuk terus menerus mengupayakan metode pembe- 
lajaran inovatif dalam rangka meningkatkan kualitas siswa yang ditandai dengan meningkatnya prestasi yang dicapai mereka. Dengan model eklektik, pembelajaran Bahasa Indonesia menjadi hidup dan menyenangkan karena semua siswa termasuk merka yang mengalami hambatan kognitif dapat belajar melalui berbagai metode sesuai dengan pengetahuan dan keterampilan yang dipelajari.

Pembelajaran Bahasa Indonesia dengan model eklektif terbukti lebih efektif dibanding dengan model konvensional. Hal ini disadari kebenarannya, karena pembelajaran dengan model eklektik menggabungkan beberapa metode yang dilahirkan teori belajar yang sesuai dengan materi yang dipelajari melalui penciptaan lingkungan pembelajaran yang kondusif. Semua teori belajar sependapat bahwa siswa belajar melalui lingkungannya. Lingkungan pembelajaran memberikan dampak terhadap proses belajar baik positif maupun negatif. Tugas guru adalah menyiapkan lingkungan positif untuk direspon siswa melalui interaksi baik sosial maupun alam sekitar yang selanjutnya dapat meningkatkan prestasi belajar.

\section{Saran}

Perubahan prestasi belajar Bahasa Indonesia ternyata bukan saja karena variasi pembelajaran melalui model eklektik, melainkan juga karena kognisi siswa sebagai modal internal dalam merespon informasi yang terkandung dalam materi ajar. Sesuai denga teori relajar baik behaviorisme maupun kognitivisme \& konstruksivisme, guru dalam hal ini diharapkan dapat responsif terhadap karakteristik siswa dari sisi kognitif. Kegiatan pembelajaran eklektik dapat dilakukan antara lain dengan menumbuhkan minat siswa, mengaitkan pembelajaran dengan pengetahuan yang sudah dimilikinya, menata materi ajar dan lingkungan belajar untuk memudahkan pemahaman siswa, membantu siswa dalam proses mencerna dan mengingat pengetahuan yang dipelajarinya.

\section{Pustaka Acuan}

Ainscow, M. 2000. The next step for special education: Supporting the development of inclusive practices; British Journal of Special Education, 27, (2), 45-69.

Bambang Saptono. 2006. Mereformasi sekolah melalui manajemen berbasis sekolah. Didaktika, 1, (1), 47-55.

Bloom. B. S. 1982. Human interactions and school learning. New York : Mc Grow - Hill

Bruning, R. 2004. Constructive psychology and instruction. New Jersey: Pierson Education, Inc

Buchori, M. 2007. Evolusi pendidikan di Indonesia. Yogyakarta: Insist Press

Burden, P. R. \& Byrd, D.M. 2003. Methods for effective teaching. Boston, MA: Allyn and Bacon.

Burstein, N; Sears, S; Wicoxson, A; Cabello, B; \& Spagna, A. 2004. Moving toward inclusive practices. Remedial and Special Education, 25, (2), 104-116

DeVries, R., Zan, B., Edmiaston, R., Sales, C. 2002. Developing constructivist early childhood curriculum: Practical principle and activities. New York and London: Teachers College Press.

Driscoll, M. P. 2005. Psychology of learning for instruction. USA: Pearson Education, Inc.

Galotti, K. 2004. Cognitive psychology. California: Wadsworths/Thomson Learning

Hallahan, D., \& Kauffman, J. 2003. Exceptional children: Introduction to special education. New Jersey: Prentice Hall International Inc.

Harwell, J. 2001. Complete learning disabilities handbook: New second edition. San Fransisco: John Wiley \& Son. Inc.

Januszewski, A. \& Molenda, M. 2008. Educational technology: A definition and commentary. New York: Taylor \& Francis Group, LLC

LaRocque, M. \& Darling, S. 2008. Blended curriculum in the inclusive K3 classroom: Teaching all young children. USA: Pearson Education, Inc. 
Parkin, A. 2000. Essential cognitive psychology. Sussex, UK: Psychology Press Ltd.

Pritchard, A. 2005. Ways of learning: Learning theories and learning styles in the classroom. London: David Fulton Publishers. Ltd.

Rukayah, Yenny, \& Gunarhadi. 2008. Korelasi kemampuan penalaran dan minat baca dengan hasil belajar keterampilan bahasa dan sastra Indonesia mahasiswa PGSD FKIP UNS; Fenolingua, Jurnal Bahasa dan Pengajarannya, 15, (2), 403-421

Salvia, J. \& Yeseldyke, J. E. 1995. Assessment. Boston : Houghton Mifflin Company.

Sekaran, U. 2003. Research methods for business : A skill building approach, New York : John Willey \& Son.

Smith, D. 2004. Introduction to special education : Teaching in an age of opportunity. Boston : Person Education, Inc.

Sutrisno Hadi. 2004. Metodologi Riset, Yogyakarta: Andi.

Solso, R. \& Mc. Lin, K. 2002. Experimental psychology: A case approach. Boston: A Pearson Education Company

Watkins, C. 2003. Learning: A sense-maker's guide. London: Association of Teachers and Lecturers

Zimmerman, B., \& Schunk, D. 2001. Self-regulated learning and academic achievement: Theoretical perspective. New Jersey and London: Lawrence Erlbaum Associates, Inc., Publishers 